\title{
Autologous Dinitrophenyl-Modified Ovarian Cancer Vaccine
}

National Cancer Institute

\section{Source}

National Cancer Institute. Autologous Dinitrophenyl-Modified Ovarian Cancer Vaccine. NCI Thesaurus. Code C78193.

A cancer vaccine consisting of autologous ovarian cancer cell peptide antigens conjug ated to the hapten 2,4-dinitrophenol (DNP) with potential immunostimulating and antineoplastic activities. Administration of autolog ous dinitrophenyl-modified ovarian cancer vaccine may induce a cytotoxic T-lymphocyte (CTL) response against ovarian cancer cells. DNP conjugation may enhance the immunogenicity of weakly immunogenic antigens. 